\title{
Muhammad: Prophet of Peace Amid the Clash of Empires
}

\author{
Juan Cole
}

New York: Nation Books, 2018. 336 pages.

Reference to violence and war often dominates contemporary discussions about the early Muslims. In Muhammad: Prophet of Peace Amid the Clash of Empires, Juan Cole balances the narrative by centering instead the role of peace and "peace thought", notions which he argues more aptly characterize the early community. He situates this emergent movement within the geo-politics of the day. As the conflict between two major super-powers became perceived as approaching cataclysmic and apocalyptic proportions, the Prophet's message juxtaposed the worldly violence of empire with the peace promised in the Quran. Within this vision lay a pursuit of temporal peace, represented by the Prophet's own political career. Departing from those scholars who either reject the later Muslim historiographical tradition out of hand or adopt it wholesale, Cole insists on centering the Quran as a primary source, while applying a discerning eye towards the hadith and biographical sources that emerge in later centuries (228). Finally, by comparing the writings of the Prophet's Christian-Byzantine contemporaries to the Quran, the author foreshadows the "violence thought" (i.e. rhetoric that justified or even encouraged aggressive warfare and conquest) that the institutionalization of power in the form of empire will soon demand of succeeding generations of Muslims.

For Cole, the story of the Prophet and the early community of believers emerges within the centuries-long power struggle between Byzantium and Persia. Just five years after the Prophet's first revelations, Khosrow the Victorious, a Zoroastrian, takes Jerusalem from the Christian Emperor Heraclius; the event is perceived as a victory for the pagan Arabs of the Hejaz while presaging doom for the nascent "believers' movement", who saw themselves as allies to the Christian West. In this maelstrom, the Prophet recites verses promising the unlikely reconquest of the Holy Land, and victory again for the People of the Book. For Cole, it is in such a context of deep foreboding and the anticipation of violence that the Quranic peace message emerges. Though identifying with the Christians, this message ultimately proposes a new vision of ecumenism that ultimately includes 
Christian, Jew, and Zoroastrian in its imaginary of "multiple peer world religions" (110).

This peace message is nuanced through the author's recognition that "both peace and war are present in the Quran." The focus of this book, however, is on peace. We learn that the foundational notion of peace lies in sakina, a divine tranquility that the believers have access to in times of deep pietistic reflection and as resolve, for example in battle (52). Sanctuary also plays an important role, denoting safety and wellbeing, and manifesting as space (e.g., the Holy Cities), time (e.g., the sacred months), and perhaps even the text of the Quran itself (e.g., 11, 14, 27). In social and political contexts, Cole insists, we find a clear inclination for both negative and positive peace (36). Negative peace is attained through wishing welfare on enemies, urging forgiveness, and strategic nonaggression (12). Positive peace is achieved through a soteriologically universal (but theological inclusive) worldview in which freedom of conscience is protected (198). Preference is given to the use of soft power and non-violent direct action, like civil disobedience and nonviolent noncooperation $(152,170)$. When violence does emerge in the Quran, it is almost exclusively as self-defense or in response to treason, and when war becomes necessity, it is always conducted in a way that is minimalist, and its referent, qitāl, is discussed in a secular context $(121,139)$. Jihad, for Cole, refers only to a general "ethical striving" (143). Finally, Quranic ideas are compared to contemporaneous Christian ones throughout the text. In comparison, the Quran presents a narrative of peace that starkly contrasts with the ideas and norms that dominated Christian thought under imperial Byzantine rule. It is not until much later, after the emergence of Islam's own great empires, that commensurate ideas on aggressive war and militarism emerge to justify the practice of warfare in those imperial contexts (129).

Cole's central thesis is that within the geo-politics of warring empires, the Prophet's movement reflected regional vocabularies and traditions to synthesize a new vision of society and human conduct that emphasized sanctuary, relative inclusivity, preferential nonviolence, and, when necessary, minimalist warfare. In comparison, contemporaries to the Prophet from the great empires emphasized religious exclusivity, the normalization of violence, and aggressive warfare. As Muslim societies developed their own empires, the early peace message of the Quran, represented by the Prophet's charismatic leadership, routinized into an authoritative legal system that later came to justify and prescribe violence and war as was consonant with medieval imperial norms. For example, to justify the new 
empires' wars of conquest, Muslim clerics developed a theory of abrogation in order to privilege the so called "sword" verse (Q. 9:5) over other peacemaking verses that came prior (203).

Now to a methodological question: what about the later Muslim historiographical tradition that would perhaps complicate this narrative of peace in the early Islamic message? For Cole, this tradition should be approached judiciously, read alongside the Quran (3). Following Angelika Neuwirth, the author takes a bottom-up approach, drawing themes from the $\mathrm{Qu}$ ran and then "listening for resonances with other works of late antiquity," namely the hadith and sira traditions, as well as non-Muslim sources from the Prophet's time (229). He dismisses as unlikely, for example, the alleged execution of male Jews of the Banu Qurayza at Khaybar, as a fanciful tale conjured by later Abbasid-era biographers. For one, the Quran fails to mention the event, alluding only to their expulsion but never to a mass death sentence. Additionally, Cole argues, the Quran condemns the tyranny of Pharaoh in the strongest terms; it is unlikely that the Prophet would directly contradict those condemnations by engaging in similar behaviors (141). Finally, the event bears suspicious similarity to earlier Christian expulsions of Jews from Roman land as well as later conflicts between Muslims and Jews during the Abbasid era (142). In this manner, by beginning with the Quran and then reflecting on accounts given by later historians, Cole weaves a narrative that centers the Quran as its primary source. At the same time, the author departs from those scholars who reject the later sources out of hand and thereby condemn "non-Europeans to being a people without a history" (4). Reference to these later sources is often light, however, as the author draws "only the broadest historical outlines and some dates" from later historians like al-Wāqidī (228). We may consider what narrative would emerge after systematic study of later sources on a topic whose matn (content) could then be put up to Quranic scrutiny. This may contribute to a privileging of the Muslim intellectual tradition as a key source of knowing, while also leaving its conclusions open to critique.

In style, Cole does not shy away from using contemporary vocabulary to describe the non-violent ethos of the Quran. For the author, the conquest of Mecca at around $630 \mathrm{CE}$ was actually a peaceful march, more akin to Martin Luther King Jr's March on Washington than a military campaign (199). Similarly, the holy cities (namely, Mecca and Medina), served as "sanctuary cities" for migrants feeling persecution (116). Even the Prophet's preference for the Roman Byzantine enterprise over the pagan Sassanians positions "Islam [as] a Western religion that initially grew up in 
the Roman Empire... Muhammad saw himself as an ally of the West" (3). These allusions, among others, suggest that a subtext is at play in which the author seeks to relate the Quranic message to contemporary audiences as non-threatening and consonant with modern, liberal norms. This seems to be a direct result of the aforementioned methodological approach. By deriving themes from the Quran without systematic reference to the secondary sources and the later historiographical tradition, the interpreter risks substituting the supposed biases of the medieval Muslim historiographers for their own. In other words, Cole's method lends itself to an imposing of the reader's subjectivities on to the Quranic message.

With this weakness in mind, the argument seems to offer a successful, if implicit, response to those who claim that violence committed by contemporary Muslims is a result of the Quran's message, as opposed to historical, political, and social realities. Particularly useful is the contextualization of the Prophet's 'peace message' within the civilizational clash occurring between Christian-Byzantine Rome and the Persian Sassanian Empire. This framing helps us imagine why the Prophet's message departed so radically from other theological and ethical systems of the day, as it challenged existing notions of peace and war, the role of sanctuary, and the norms governing human social life and interaction. Finally-in a message that is relevant now as then-the book argues that empire will often bend social norms and mores to better reflect and accommodate its raison dêtre: conquest and control.

Ahmed Z. Mitiche MA student, Middle Eastern and North African Studies University of Michigan, Ann Arbor 